Apidologie, 1977, 8 (4), 349-356.

\title{
NON-SUGAR CHEMICAL CONSTITUENTS OF NECTAR
}

\author{
Herbert G. BAKER (1) \\ University of California, Berkeley, California 94720, U.S.A.
}

\section{SUMMARY}

This brief review describes and discusses some chemical substances that have been found in a synoptic survey of flowering plant nectars. The ever-present sugars are not considered. Amino acids are universally present, in amounts up to about $4 \mathrm{mg} / \mathrm{ml}^{-1}$. Nectars are richer in amino acids if the flowers that produce them are pollinated by settling moths, butterflies and many wasps which, as adults, do not have alternative sources of protein-building materials. They are weaker in the cases of flowers pollinated by bees and bats (which utilize pollen as a nitrogen source) and birds that catch insects. In addition to potentiality for increasing life span and reproductive output of pollinating insects, amino acids in nectars of all kinds may help to privide a distinctive ( taste " to the nectar of each species. Nectar amino acid complements appear to be strictly controlled genetically; these complements have a use in taxonomic and phylogenetic studies of congeneric species. Extra-floral nectar produced on the same plant as floral nectar has a different amino acid complement.

The occurrence of lipids and antioxidants (including ascorbic acid) in a minority of nectars is described in the double context of flower-visitor nutrition and nectar-taste modification. Similar consideration is given to chemicals potentially deterrent to nectar consumers (alkaloids, phenolic substances and glycosides). Inorganic substances in nectar and pH characteristics of nectars are only just beginning to be studied.

\section{I. - INTRODUCTION}

Except for the water in which they are dissolved, sugars are present in all floral nectars in greater amount than any other constituent. Nevertheless, it is the object of this paper to point out that the biological impact of the other constituents is worthy of further study. A wide range of ( minor ) constituents has been identified by biochemists during the present century, and a review of the literature has been published by BAKER and BAKER (1975). Here, I wish to refer only to four classes of nectar-constituent : amino acids, 
lipids, antioxidants, and a heterogeneous group of potentially toxic substances (including " non-protein amino acids », alkaloids, phenolics and glycosides).

\section{II. - AMINo ACIDS}

Beginning with ZIEgLER (1956), a small number of European investigators reported the presence of amino acids in the floral nectars of a limited number of species (see BAKER and BAKER, 1975, for a historical listing). In 1973, my wife and I produced the first of a series of papers (BAKER and BAKER, 1973a, b, 1975, 1976a, b, 1977; BAKER, 1978) in which we have shown by ninhydrin staining the easily detectable presence of amino acids in the nectars of virtually all of over 1000 species. We have measured their approximate concentrations in each case and, using thin-layer chromatography (of the dansyl derivatives of the amino acids) on polyamide plates, we have identified the actual amino acids present in over 350 of these samples (BAKER and BAKER, 1976a, b; 1977; BAKER, 1978).

Our results show that the concentration of amino acids in a nectar is greater if nectar is the chief source (or only source) of protein building material for the usual visitors to the flower producing it. It is markedly lower if the visitors have an abundant alternative source of protein building amino acids. Thus, from Table 1, it may be seen that the nectar of flowers visited by settling moths butterflies and many wasps, which depend upon nectar for their nourishment, have relatively high amino acid concentrations. By contrast, bees make use of pollen as a source of amino acids for their own nourishment and that of their larvae, and “ bee-flower " nectars show a lesser concentration of amino acids.

TAB. 1. - Average amino acid concentrations in floral nectars, grouped according to principal type of pollinator. Determinations made at Berkeley from nectar collections in various temperate and tropical regions.

\begin{tabular}{|c|c|c|}
\hline $\begin{array}{l}\text { Principal } \\
\text { pollinator }\end{array}$ & $\begin{array}{l}\text { Number of } \\
\text { determinations }\end{array}$ & $\begin{array}{c}\text { Amino acids in } \\
\text { micromoles per ml }\end{array}$ \\
\hline Bees $\ldots \ldots \ldots$. & 515 & 0.702 \\
\hline Wasps ....... & 38 & 0.975 \\
\hline Butterflies............. & 124 & 1.186 \\
\hline Settling moths .. & 65 & 1.178 \\
\hline Hawk moths .... & 59 & 0.550 \\
\hline Flies (general) $\ldots \ldots \ldots \ldots \ldots$ & 89 & 0.573 \\
\hline Carrion \& dung flies $\ldots \ldots \ldots$ & 9 & 12.500 \\
\hline Old World birds . ......... & 21 & 0.255 \\
\hline Hummingbirds . . . . . . . . . & 104 & 0.452 \\
\hline Bats $\ldots \ldots \ldots \ldots \ldots \ldots$. & 19 & 0.302 \\
\hline
\end{tabular}


Flower-visiting bats in tropical countries make use of fruit-juices and pollen as sources of protein-building materials and those that belong to the neotropical Microchiroptera also catch some insects (BAKER, 1973, 1978). The nectars that they take are weak in amino acids. Hummingbirds are avid insect-catchers; flowers could hardly provide them with a significant alternative supply of protein-building materials-and they do not.

Hawkmoths (Sphingidae) imbibe large quantities of nectar each night and the amino acid concentration in these nectars is low; nevertheless, the total amount ingested may be high. Another anomaly is provided by the nectar of flowers (e.g. Stapelia grandiflora) that lure female dung-and carrion-flies to oviposit on them instead of on faeces and decaying flesh. The allurement of these insects is provided by color (often brownish-purple), smell (unpleasant to the human nose) and an extremely high amino acid content of the nectar when this is provided (Table 1). On the other hand, nectars from "generalized" fly flowers have relatively low amino acid contents.

The conclusion that we may draw is that for the settling moths, butterflies and wasps, the amino acids may perform a nutritive function (BAKER and BAKER, 1973a, b, 1975). This is further suggested by feeding experiments with Colias butterflies (Watt, Hoch and Mills, 1974) and butterflies of several species (Arms, Feeny and Lederhouse, 1974). Interestingly, among birds, Cruden and Hermann-Parker (1977) have found that hooded orioles and Bullock's orioles in Mexico defend feeding-territories made up by trees of Erythrina breviflora (Leguminosae-Fabaceae) on which enough nectar was provided to satisfy the nutritional requirements of the birds, without resort to insect-catching. The nectar of $E$. breviflora, which contains a total of $3.88 \mathrm{mg} / \mathrm{ml}^{-1}$ of amino acids, is the first that we have analyzed that contains all ten of the "essential" amino acids in the same nectar (BAKER, 1978).

Even in those cases where the concentration of amino acids is too low for them to be likely to be of direct nutritional significance, it is probable that their presence, proportions and concentrations have significance for the animal that drinks the nectar. Even to the human palate, some nectars are sweet, some are sour and some are bitter. Shiraishi and Kuwabara (1970) have shown that some insect chemoreceptors react differentially to similar groups of amino acids (although, unfortunately, the experimental chemoreceptors were provided by flies that are not primarily flower-visitors). Consequently, we may believe that amino acids in particular combinations may affect the " taste" of nectar and, along with the sugars, may reinforce the morphology, color and scent of flowers in enabling the flower visitor to build a relationship with a particular flower species.

If this function is to be performed, it is important that the amino acid complement of each species' nectar be under tight genetic control, and remain 
constant in the face of environmental variation. That this is true to a remarkable extent has been shown by BAKER and BAKER (1976a, 1977).

An interesting fact, congruent with the suggestion that nectar amino acids play a significant role in pollination ecology, is that their concentration and the number of acids in the complement both tend to be less in the nectar that is produced by nearly autogamous relatives of allogamous species, e.g. Silene noctiflora compared with Silene alba.

In our amino acid analyses, certain acids occur very frequently : alanine and arginine are present in virtually every case; serine, threonine, proline and glycine are almost as frequently found. At the other extreme, the sulfurcontaining methionine is relatively rare, as is histidine. Glutamine is rather rare compared with glutamic acid and asparagine is much less common than aspartic acid.

Nectar amino acid complements not only show a high degree of constancy within species, but closely related species tend to show similar (but not identical) complements (BAKER and BAKER, 1976a, 1977); these complements are additive in $F_{1}$ and in amphidiploids derived from them, but are recombined when hybrid swarms are formed (BAKER and BAKER, 1976a, 1977). Consequently, they can be valuable in taxonomic and phylogenetic studies.

Nectar produced by extra-floral nectaries usually has a different amino acid complement from that produced by floral nectaries on the same plant (BAKER and BAKER, in prep.). This may be related to the different guild of feeders at such nectar (usually ants, wasps, etc.).

In addition to those amino acids that take part in protein-building, one or more " non-protein" amino acids are found in over one third of the nectarspecies sampled. For example, nectar from Umbellularia californica (Lauraceae) contains $\beta$-alanine, $\gamma$-amino butyric acid, ornithine and one unknown acid, along with 16 protein-building acids. The ecological significance of the presence of non-protein amino acids in nectar is not yet ascertainable, but it is likely that at least some of them will prove to be toxic to certain kinds of flower-visitor.

\section{III. - LIPIDS AND ANTIOXIDANTS}

Some years ago, Vogel $(1969,1971,1974)$ drew attention to the production by flowers of some species of the families Malpighiaceae, Scrophulariaceae, Krameriaceae, Iridaceae and Orchidaceae of oil-drops that, in his opinion, represented an alternative " strategy" in anthophilous insect-reward to the production of aqueous, sugar-containing nectar. However, BAKER and BAKER (1973b, 1975) and BAKER (1978) have demonstrated that about one-third of all 
nectars sampled contain lipids in solution or suspension, in some cases in quantities sufficient to give a milky appearance to the nectar. In tropical habitats, lipid-containing nectar appears to be particularly frequent in the Bignoniaceae and Caesalpiniaceae, and at higher latitudes, in the Saxifragaceae. At least in some cases, chromatographic separations have shown that the lipids are saponifiable lipids but the possibility cannot be excluded that in some cases, unsaponifable lipids (e.g. steroids and terpenoids) are involved.

Nectars that contain lipids also frequently contain antioxidant organic acids, notably ascorbic acid (vitamin $\mathrm{C}$ ), which may play a rancidity-preventing role.

\section{IV. - Potentially DeterRent SUBStances}

There are other, scarely nutritious substances that can be found in nectar which may have an effect upon the taste of the nectar as well as possibly having a significant effect upon the central nervous system of a flower-visitor (see BAKER and BAKER, 1975, for a historical review). These chemicals include alkaloids, glycosides, and phenolic substances. We have first-hand evidence of the presence of alkaloids and phenolics in a minority of nectars tested (BAKER and BAKER, 1975 and unpub.). Alkaloids have been detected by means of the iodoplatinate and Dragendorff tests (BAKER and BAKER, 1975), phenolics by color-testing with p-nitraniline (BAKER and BAKER, unpub.). Very recently, Deinzer, Thomson, Burgett and Isaacson (1977) have reported the presence of pyrrolizidine alkaloids in honey from Senecio jacobaea (Compositae).

If these substances, like non-protein amino acids, serve to cut down the list of visitors to flowers (presumably deterring those whose visits do not result in cross-pollination), they should be particularly likely to be found in nectar from plants growing in habitats where the greatest variety of potential flowervisitors occurs. Preliminary evidence that this is the case is given in Table 2, where the proportions of species whose nectars we have found to contain alkaloids and phenolics over a "transect "from lowland Costa Rica to the alpine tundra of the Rocky Mountains in the state of Colorado, U.S.A. is shown (see, also, BAKER, 1978). Both alkaloids and phenolics decline in frequency of occurrence from the tropical lowlands (with an abundance and diversity of flower-visitors) to the sparse community of bumble-bees and flies of the Colorado alpine zone.

Inorganic cations, such as potassium, may be present in onion-flower nectar in quantities sufficient to discourage bee visits (WALLER, 1973). This information, and our own experience that the $\mathrm{pH}$ values of nectars may range, at least, from $\mathrm{pH} 4.2$ (in Zauschneria garrettii, Onagraceae) to $\mathrm{pH} 8.5$ (in 
Rhododendron spp., Ericaceae) indicate that we have not yet reached the limit of understanding of nectar-composition. No longer to be regarded as a simple solution of sugars in water, nectars contain an impressive array of substances regularly or occasionally present in modest concentrations. These substances cannot be dismissed as biologically insignificant and they deserve more study from several points of view.

TAB. 2. - Frequencies of occurrence of nectars containing alkaloids and phenolics, respectively, in plants of all life forms on a transect from lowland forest in Costa Rica to the alpine tundra of Colorado U.S.A., (BAKER, 1978).

\begin{tabular}{|c|c|c|c|c|}
\hline & \multicolumn{2}{|c|}{ Alkaloids } & \multicolumn{2}{|c|}{ Phenolics } \\
\hline & $\begin{array}{c}\text { Number of } \\
\text { spp. examined }\end{array}$ & $\begin{array}{l}\text { \% with } \\
\text { alkaloids }\end{array}$ & $\begin{array}{c}\text { Number of } \\
\text { spp. examined }\end{array}$ & $\begin{array}{r}\text { \% with } \\
\text { phenolics }\end{array}$ \\
\hline Costa Rica - lowland forest $\ldots \ldots \ldots$ & 198 & 12.2 & 164 & 50.6 \\
\hline California - below $2,438 \mathrm{~m} . \ldots \ldots \ldots$ & 275 & 6.9 & 248 & 31.0 \\
\hline California - above $2,438 \mathrm{~m} . \ldots \ldots \ldots$ & 67 & 7.4 & 54 & 29.6 \\
\hline Colorado - subalpine forest $\ldots \ldots \ldots \ldots$ & 27 & 7.4 & 31 & 29.0 \\
\hline Colorado $\longrightarrow$ alpine tundra $\ldots \ldots \ldots \ldots$ & 26 & 0 & 31 & 19.4 \\
\hline
\end{tabular}

Received in April 1977.

\section{RÉSUMÉ

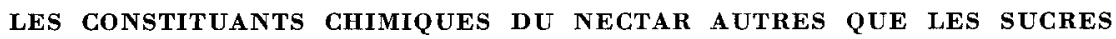

Cette courte mise au point décrit et commente certaines substances qui ont été trouvées lors d'une étude synoptique des nectars de plantes à fleurs. On ne traite pas des sucres omniprésents. Les acides aminés se rencontrent partout en quantités allant jusqu'à $4 \mathrm{mg} / \mathrm{ml}^{-1}$. Les nectars sont plus riches en acides aminés si les fleurs qui les produisent sont pollinisées par les papillons de jour, les papillons de nuit et par de nombreuses guêpes qui, lorsqu'ils sont adultes, n'ont pas d'autres sources d'éléments constitutifs des protéines. Ils sont moins riches dans le cas où les fleurs sont polinisées par les abeilles et les chauve-souris (qui utilisent le pollen comme source d'azote) et par les oiseaux qui capturent des insectes. En plus de leur pouvoir à accroître la durée de vie et le taux de reproduction des insectes pollinisateurs, les acides aminés présents dans les nectars de toutes espèces peuvent contribuer à donner un " goût 》 différent au nectar de chaque espèce. Les compléments des acides aminés dans le nectar semblent déterminés strictement génétiquement; ils sont utilisés dans les études de taxonomie et de phylogenèse des espèces congénériques. Le nectar extrafloral produit par la même plante que le nectar floral a un complément d'acides aminés différent.

La présence de lipides et d'antioxidants (y compris l'acide ascorbique) dans une minorité de nectars est décrite dans le double contexte de la nutrition du visiteur de la fleur et de la modification du goût du nectar. On considère sous le même angle les composés qui possèdent une action potentiellement dissuasive vis-à-vis des consommateurs de nectar (alcaloïdes, phénols et glucosides). On commence seulement à étudier les substances inorganiques et les caractéristiques du $\mathrm{pH}$. 


\section{ZUSAMMENFASSUNG}

\section{CHEMISCHE BESTANDTEILE DES NEKTARS, DIE KEINE ZUCKER SIND}

In diesem kurzen Überblick werden einige chemische Substanzen beschrieben und besprochen, die bei einer zusammenfassenden Überprüfung von Nektaren blühender Pflanzen gefunden wurden. Die immer vorkommenden Zucker wurden nicht berücksichtigt. Aminosäuren sind allgemein vorhanden, und zwar in Mengen bis zu $4 \mathrm{mg} / \mathrm{ml}^{-1}$. Nektar ist reicher an Aminosäuren, wenn die ihn liefernden Blüten von sich niederlassenden Nachtfaltern (Heterocera), Tagfaltern (Rhopalocera) und solchen Wespen bestäubt werden, denen als Adulte keine anderen Quellen proteinbildender Substanzen zur Verfügung stehen. Nektar ist ärmer an Aminosäuren, wenn die Blüten von Bienen bestäubt werden oder von Fledermäusen (die den Pollen als Stickstoffquelle nutzen) oder auch von Insekten-fangenden Vögeln. Zusätzlich zu ihrer Fähigkeit, Lebensdauer und Fortpflanzungsvermögen der bestäubenden Insekten zu verlängern, bzw. zu verbessern, können Aminosäuren in Nektaren aller Art dazu beitragen, einzelnen Nektaren einen besonderen “ Geschmack 》 zu verleihen. Die Aminosäuren-Komplemente im Nektar scheinen genetisch genau festgelegt; sie sind bei taxonomischen und phylogenetischen Untersuchungen verwandter Arten von Nutzen. Extrafloraler Nektar weist ein anderes Aminosäuren-Komplement auf als der von der gleichen Pflanze erzeugte Blütennektar.

Das Vorkommen von Lipiden und Anti-Oxydantien (einschliesslich Ascorbinsäure) in einer geringen Zahl von Nektaren wird im doppelten Zusammenhang von Ernährung des Blütenbesuchers und modifiziertem Nektargeschmack gesehen. Ähnliche Überlegunegn werden bei Chemikalien angestellt, die möglicherweise abstossend auf Nektarsammler wirken (Alkaloide, Phenole, Glykoside). Untersuchungen von anorganischen Stoffen im Nektar und von $\mathrm{pH}$-Eigentümlichkeiten des Nektars befinden sich erst im Anfangsstadium.

\section{REFERENCES}

Arms K., Feeny P., Lederhouse R.C., 1974. - Sodium : stimulus for puddling behavior by tiger swallowtail butterflies, Papilio glaucus. Science, 185, 372-274.

BAKER H. G., 1973. - Evolutionary relationships between flowering plants and animals in American and African forests. In Tropical Forest Ecosystems in Africa and South America : A Comparative Review (ed. by B.J. Meggers, E.S. Ayensu and W.D. Duckworth, p. 145159 (Chap. 11). Smithsonian Institution Press, Washington, D.C.

BAKEn H. G., 1978. - Chemical aspects of the pollination biology of woody plants in the tropics. In Tropical Tress as Living Systems (ed. by P.B. Tomlinson and M. Zimmermann). Cambridge University Press, New York.

BaKer H. G., BaKer I., 1973a. - Amino acids in nectar and their evolutionary significance. Nature 241, 543-545.

BAKER H. G., BAKER I., 1973b. - Some anthecological aspects of the evolution of nectarproducing flowers, particularly amino acid production in nectar. In Taxonomy and Ecology (ed. by V.H. Heywood), p. 243-264 (Chap. 12). Academic Press, London.

BAKER H. G., BAKER I., 1975. - Studies of nectar-constitution and pollinator-plant coevolution. In Coevolution of Animals and Plants (ed. by L.E. Gilbert and P.H. Raven), p. 100140. University of Texas Press, Austin.

BAKEн H. G., BaKer I., 1977. - - Intraspecific constancy of floral nectar amino acid complements. Bot. Gaz., 138, 183-191.

Baker I., BaKer H. G., 1976a. - Analyses of amino acids in flower nectars of hybrids and their parents, with phylogenetic implications. New Phytol. 76, 87-98. 
Baker I., Baker H. G., 1976b. - Analysis of amino acids in nectar. Phytochem. Bull. 9, 4-7. Cruden R. W., Hermann-Parker S., 1977. - Defense of feeding sites by orioles and hepatic tanagers in Mexico. Auk (in press).

Deinzer M. L., Thomson P. A., Burgett D.M., IsaAcson D.L., 1977. - Pyrrolizidine alkaloids : Their occurence in honey from tansy ragwort (Senecio jacobaea L.). Science 195, 497-499.

Shiraishi A., Kuwabara M., 1970. - The effect of amino acids on the labellar hair chemosensory cells of the fly. $J$. gen Physiol. 56, 768-782.

Voget S., 1969. - Flowers offering fatty oil instead of nectar. Abstracts XI International Bot. Congress, Seattle, p. 229.

VoGEL S., 1971. - Ölproduzierende Blumen, die durch ölsammelnde Bienen bestäubt werden. Naturwissenschaften $58,58$.

VogeL S., 1974. - Ölblumen und ölsammelnde Bienen. Tropische und Subtropische Pfanzenwelt 7, 285-547.

WaLLer G.D., 1973. - Chemical differences between nectar of onion and competing plant species and probable effects upon attractiveness to pollinators. Ph. D. thesis, Utah State University.

Watt W.B., Hoch P.C., Mrlcs S.G., 1974. - Nectar resource use by Colias butterflies : Chemical and visual aspects. Oecologia (Berl.) 14, 353-374.

Zregler H., 1956. - Untersuchungen über die Leitung and Sekretion der Assimilate. Planta (Berl.) 47, 447-500. 